\title{
The Evasion of Conversion in Recent American Philosophy
}

I COME NOW to the conclusion of this argument for returning a consideration of conversion to American philosophy. I first found this issue emerging with my reading of the classical figures of pragmatism, Peirce, Dewey, and James. The pressure of their thought toward a transformation that carries persons into an active and extendable relation with their community and with reality most broadly conceived held me, and still holds me, in their thought. So strong was this impulse toward transformation in their thought that I expected it to be clearly repeated and extended in the philosophical work that flows in response to them. But I did not find things as I expected. By and large the argument for transformation is sublimated by the philosophical warrant of making a better argument than the previous commentator, or getting to the truth about $\mathrm{X}$ within the thought of A, B, or C. I missed the holism, the comprehensive word about what we are up to. What happened to conversion? This remains my question.

The rekindling of interest in American philosophers such as Peirce, James, and Dewey has produced an abundance of critical work on pragmatism and its origins. There are also signs of an extension of pragmatism in contemporary philosophical discourse, but not yet with the power that these "founders" possessed. I think one of the reasons for this lack of power is that the idea of transformation has been left for some other goal such as philosophical currency or historical curiosity. There are many attempts to repeat, codify, classify, and honor the original arguments that developed into pragmatism, but there is little awareness that anything more can or should be done, or what may be required of us as the people who hold ourselves apart as intellectuals and teachers of the next generation. We have produced philosophically exactly what we want-a safe haven, free to explore reason at its limits, secure from any truth that might grip us and toss us into the rough and tumble of life. We have domesticated pragmatism and made it into a cultural artifact, a banner to wave, an allegiance to 
a set of thinkers who stand opposed to another set of thinkers, a way of reading the history of philosophy that points to the "truth" as all that we can expect, or all that we can justify. We have for all intents evaded the demand for transformation that sponsored the tradition we laud.

We are not alone, however, and there is comfort, if not satisfaction, in numbers. From time to time a person emerges who seeks to disrupt this comfort and challenge our sanctified tradition with a new reading or a new demand on philosophy. Their mistaken understandings are pointed out, the tradition is reaffirmed in its ability to resist yet another level of criticism, and things go on. But we are waiting, waiting for another person like Dewey, who can reorient the philosophical ground on which we are standing. Or a person like James, who can affect a role in our culture that transcends the divisions between philosophy and religion by virtue of an analysis that strikes to the core of our souls. Or a person like Peirce, who, almost unseen, drives an argument about the structure of inquiry into the very heart of our understanding of ourselves and the human enterprise. We wait for someone who does not stand on the periphery of reflective life, snipping at the edges with a new and momentarily fashionable critique, but one who is able to bring an epoch-making reorientation.

In this chapter I focus on three philosophers whose thought moves toward this reorienting change. Richard Rorty has most nearly approached this kind of stature and effect in American philosophy, although I will argue here that he avoids the fundamental issue of personal transformation, which his own argument demands. Cornel West has attained the public notoriety of an intellectual with a program for transformation, drawing on Christian and philosophical resources for his sermonic challenge to culture. West also evades conversion, but differently than Rorty. Conversion is central to West's self-understanding, but it falls out of his programmatic speech. West fails to establish the ground from which others might enter the same converted place as West himself. Robert Corrington approaches philosophy from within the American perspective, but draws its thought up into the ongoing challenge of consciousness with itself. Transformation of human consciousness is the reality Corrington approaches from a platform of ecstatic naturalism. He shows how thought that is held between the demands of coherence and obligation evades conversion in order to sustain inquiry, and at what cost this evasion is made. 
These three voices correspond in tone to James, Dewey, and Peirce, respectively. Rorty shares James's rejection of authority, West reflects Dewey's aim for a philosophical speech that obliterates the distinction between fact and value, and Corrington emulates Peirce's pursuit of the origin of inquiry. My argument is that these three voices represent what American philosophy has come to. They are, in a sense, the fruits by which we know who we are. Conversion is only the linking clue that can hold these personalities and reflection together long enough for us to develop a clear idea of what transformation means for us, and what sort of platform we may yet need to construct to further the project of understanding the ways we can change and should change, both ourselves and our communities.

\section{Rorty AND the Transformation OF Philosophy}

Few books have had the epoch-making effect of Richard Rorty's Philosophy and the Mirror of Nature and Consequences of Pragmatism. Rorty aims for and achieves a kind of transformation of philosophy by following out the problematic dimensions of analytic thought in Quine, Sellars, and Davidson, showing that the path analytic philosophers are traveling is a dead end. The way out is pragmatism. "On my view," Rorty says in the introduction to Consequences of Pragmatism, "James and Dewey were not only waiting at the end of the dialectical road which analytic philosophy traveled, but are waiting at the end of the road which, for example, Foucault and Deleuze are currently traveling." ${ }^{1}$ Rorty is not concerned to extend philosophy in its current form but to affect a complete transformation to what he calls "pragmatism."

Rorty's entrance into this transformational project comes from his interest in setting to rights philosophy's epistemic expectations and methodological controls. The analysts, Rorty claims, lost the control of knowledge they sought, finding instead a refurbished Platonism. The transformation this failure indicates, though, is not a change of discrete conclusions, or a shift of emphasis on problems from one sort to another. A complete turning over of philosophy is required, for philosophy is its own problem. Only by "extirpating" the ground of epistemic expectations that Philosophy should or could produce a description of the "world" that would be True universally and eternally, will philosophy really get going again on the problems of men and women and science. 
Rorty's transformation of philosophy requires a death and resurrection. Robert Brandom summarizes Rorty's impact this way:

In his classic work, Philosophy and the Mirror of Nature, he notoriously prophesized approvingly the "death of philosophy." Although he now regrets this bit of rhetoric-he certainly never meant to deny that we would always need professors to help students read the great books that make up the philosophical tradition, for instance- he has never relinquished his commitment to the dissolution of a certain sort of philosophy: philosophy as a discipline with epistemology at its heart, a sort of superscience, limiting the limits of the knowable, explaining the nature of the relationship between reality and our representations of it. ${ }^{2}$

Despite the "dissolution" of philosophy as a discipline with epistemology at its core, Rorty continues to focus on the problems of epistemology as the main route into his criticism. In his ongoing conversations with Jürgen Habermas and others, Rorty continues to answer the question "What was Epistemology?" ${ }^{3}$ His arguments against representationalism focus not so much on the method of analysis and argument, but on the goals and final expectations of all such enterprises. The epistemological failure of analytic philosophy is in supposing that eternal verities in any form, call them science or language, correspond to a discoverable telos of inquiry. Rorty's self-imposed task is "to dissolve the modern version of the problem of reason-the notion that there is a problem about the possibility or extent of accurate representation which is the concern of a discipline called 'epistemology' Insofar as it succeeds, this attempt frees us from the notion of human knowledge as an assemblage of representations in a Mirror of Nature, and thus reinforces the claim of part I that we can do without the notion of our Glassy Essence." 4 Setting aside the reality of these verities is part and parcel of Rorty's transformation of philosophy. This means that philosophy does not have a goal intrinsic to its own practice that it can hope to complete. It also means that human culture, which alone is the content of all reflection, also has no final good or standard to be achieved. Rorty, however, does not collapse into a fashionable nihilism that disestablishes the possibility for a warrantable standard of human life; he simply argues against the advisability of looking for any such warrantable condition or standards. Philosophy must change its own expectations and must change the expectations of the wider community. Contingent narrative is all there is, and suggestions to the contrary are evasions of the necessary and coming transformation. 
Rorty takes up pragmatism as the activity of dispelling any authority that challenges the contingency of life.

So my preferred narrative is a story of human beings as having recently gotten out from under the thought of, the need of, authority. I see James's suggestion that we carry utilitarianism over from morals into epistemology as crucial to this anti-authoritarian movement of the spirit. For James shows us how to see Truth not as something we have to respect, but as a pointless nominalization of the useful adjective we apply to beliefs that are getting us what we want. ${ }^{5}$

The conversion Rorty requires in philosophy is taking up this authority for itself, embracing its power that it is not derivative on any good or ideal, but dependent only on human enterprise that knows itself for what it is, simply its own enterprise.

From the philosophy of Dewey and James, Rorty constructs the "pragmatist." The pragmatist is the one disabused of philosophical expectations of authority, fully embracing the thoroughgoing linguistic character of human reality, able to withstand the tendencies that lead back to intuitions of morality or Truth. "He is a pragmatist just because he doesn't have such intuitions (or wants to get rid of whatever intuitions he may have)." ${ }^{\prime 6}$ Further, Rorty says, "the pragmatist is urging that we do our best to stop having such intuitions, that we develop a new intellectual tradition." 7 The pragmatist is concerned about not only developing a personal character but also promulgating this character as the ground of a proper vision of small-p philosophy. This is not an easy transition. It requires a platform of objective disengagement from the intuitions that appear organically as the guiding premises of our reflective lives. The "pragmatist" must make a compelling argument that whatever ground is attained by these intuitions, it is a false and dangerous ground.

So the pragmatists' quarrel with the intuitive realist should be about the status of intuitions-about their right to be respected-as opposed to how particular intuitions might be "synthesized" or "explained away." To treat his opponent properly, the pragmatist must begin by admitting that the realistic intuitions in question are as deep and compelling as the realist says they are. But he should then try to change the subject by asking, "And what should we do about such intuitions-extirpate them, or find a vocabulary which does justice to them?"

Changing the subject from these intuitions does not challenge them on the basis of coherence or consistency, but it enables the pragmatist to say 
"his only argument for thinking that these intuitions and vocabularies should be eradicated is that the intellectual tradition to which they belong has not paid off, is more trouble than it is worth, has become an incubus." 8 And having not "paid off" properly, this tradition must be replaced with another, determined by the character of the pragmatist who alone is able to place himself (for clearly the pragmatist is Rorty) into a framework of reflection that might constitute a new postPhilosophical culture.

A post-Philosophical culture, then, would be one in which men and women felt themselves alone, merely finite, with no links to something Beyond. On the pragmatist's account, positivism was only a half-way stage in the development of such a culture - the progress toward, as Sartre puts it, doing without God. For positivism preserved a god in its notion of Science (and in its notion of "scientific philosophy"), the notion of a portion of culture where we touched something not ourselves, where we found Truth naked, relative to no description. ${ }^{9}$

This is not just a philosophical conclusion. This is a new way of living in relation to the traditions of philosophy and value. As it is clear from Rorty's reference to Sartre here, this requires a disabused notion of the world of religion too, since this is the great propounder of intuitions that are not paying off. Rorty goes a further step in claiming that the pragmatist must give up the very notion that there is a place to inhabit, a world, constructed in opposition to other worlds, from which a person can move by identification and difference. In "A World Well Lost," Rorty treats what must be eliminated of religious culture. From Wittgenstein's comment that Philosophical Investigations ends philosophy, Rorty adds that this

can only mean that this book might somehow rid us of "the picture which held us captive" - the picture of man which generates the traditional problems. To say that philosophy might end is not to say that holding large views might become unfashionable or that philosophy departments might be plowed under, but rather to say that a certain cultural tradition might die out. If this change occurred, one would no longer think of the standard list of Cartesian problems as a Fach: rather, one would think study of the concern that once was felt about these problems as a Fach. The best analogy available is the shift from "theology" to "the study of religion." Once grace, salvation, and the Divine Nature were subjects of study; now the fact that they were so is a subject of study. Once theology was a pure autonomous subject; now religion lies at the 
mercy of psychology, history, anthropology, and whatever other discipline cares to jump in. Once we had a picture of man as held in the hand of God, and a discipline which discussed alternative ways of describing the fact. ... We had a discipline which discussed these various alternativesnever questioning that there was something of central importance which needed to be said about the relation between man and nature: some bridge to be built, some dualism to be transcended, some gap to be closed. If philosophy comes to an end, it will be because this picture is as remote from us as the picture of man as a child of God. If that day comes it will seem as quaint to treat a man's knowledge as a special relation between his mind and its object as it now does to treat his goodness as a special relation between his soul and God. ${ }^{10}$

The relation between the overcoming of Philosophy and the overcoming of religion in these lines is fascinating. Does the one make the other possible? Are they analogically related, so that the authority of God dispelled in people like Sartre becomes a sign of the same dislocation necessary or possible in Philosophy? The transformation of Philosophy that would bring it to an "end" implicates the rejection of conversion, that there might be transforming grace in the world, that God might hold us as children, seeking our good. Ending Philosophy means, above all evading this object. I do not think Rorty's use of Christian imagery here is coincidental, merely an example he throws up for rhetorical effect. Disestablishing these worlds of Christianity and Philosophy, finding them "quaint," is embedded in Rorty's family past. What he rails against is not just based on a critical evaluation about what is the case about reason. His passion reveals a personal reaction to the fear of being judged or obligated against one's will or in relation to an authority one recognizes and resists. His passion is much like his mother's, recorded here in a response to her father, the eminent theologian and social-gospeler Walter Rauschenbusch. She writes,

Can't you see, Father dear, that in spite of the fact that you've captured the most wonderful reputation in the Rauschenbusch family, that the greatest good of your children may be secured not by their conservation of your policy, but by having metal enuf [sic] to step off by themselves? ${ }^{11}$

Rorty is seeking justification for his having "mettle enough" for this same stepping off that requires him to lose whatever world there once was for him or any other, but that still leaves him bound to have a response that pays off in the social sense of his grandfather's idealism. 
Rorty's stepping off is philosophically supported by a synthesis of Heidegger's analysis of the trajectory of Western philosophy and Dewey's move to a historicized development of the democratic community. What Heidegger accomplishes is the articulation of the desire for a humanness not determined by Being, even though this is still a philosopher's problem for him. In "Overcoming the Tradition" Rorty says, "Heidegger's weakness was that he could not escape the notion that the philosophers' difficulties are more than just philosophers' difficulties - the notion that if philosophy goes down, so will the West. . . Heidegger helps preserve all that was worst in the tradition which he hoped to overcome."12 Although Heidegger does not escape his own critical web, he is able to formulate the threat to which philosophy is most likely to succumb:

For Kierkegaard, the opposite of Socratism was Christianity-the claim that man is not complete, is not in the truth, but rather can attain truth only by being re-created, by being made into a New Being by Grace, Kierkegaard thought that Socratism was Sin, and Sin was the attempt by Man to assume the role of God, an attempt which found its reductio in Hegel's system. A lot of Heidegger can profitably be read as a reflection on the possibility that Kierkegaard was right to reject Socratism but wrong to accept Christianity-or, more generally, on the possibility that humanism and Pauline Christianity are alternative forms of a single temptation. ${ }^{13}$

If much of Heidegger can be profitably read in light of this single temptation, much of Rorty can be profitably read as a reflection on the certainty that we are right to reject Christianity, but wrong to accept anything in its place. How to get to this middle ground of rejecting and not accepting, avoiding this other temptation, is the test of Rorty's philosophical vision. He moves philosophically between hoping this failed hope will die of its own weight of failure, and the philosophical impulse to move beyond such vain hope to what might actually be warrantable. Heidegger can only stand in the current of thought and suffer nostalgically for man before Being.

Heidegger would like to recapture a sense of what time was like before it fell under the spell of eternity, what we were like before we became obsessed by the need for an overarching context which would subsume and explain us-before we came to think of our relation to Being in terms of power ... to recapture a sense of contingency of the fragility and riskiness of the human project. ${ }^{14}$ 
Rorty synthesizes Heidegger's sense of contingency with the "downward escalator ride" to pragmatism, to human will not as will-to-power, but simply as power. This realization of the nexus of power is the proper place for human thought to dwell, where Dewey looks with wonder at the world as the interest of humans in themselves and their environment as all that can be or needs to be understood as Being or Real. Rorty asks, "Can pragmatism let us hear as well as use?" Answering, he says, "Yes, I see Dewey's pragmatism as putting technology in its proper place, as a way of making possible social practices (linguistic and other) which will form the next stanza of Being's poem." Dewey seeks "to combine the vision of a social democratic utopia with the knowledge that only a lot of hard work and blind luck, unaided by any nonhuman power called Reason or History, could bring that utopia into existence." 15 The crux of Rorty's synthesis is that philosophy has brought us to the end of hope, exactly where we need to be. We (pragmatists) just need a push to realize that this place is ours, the only platform from which we can productively work without reifying our hopes into ideals, where technology rules not only our experience but also whatever is left of our souls.

I will not stop to examine Rorty's interpretation of Dewey here, but I will say that Rorty completely covers over Dewey's “sense of a good world" that, though lost, still remains powerful. There is more transcendental meat to Dewey's common faith than Rorty wants to acknowledge. But my question is how Rorty understands the motive for this transformation in philosophy. Why make the push to disestablish what others hold, even if they are wrong? If this activity is not for the good of Philosophy, and not for a more accurate understanding of an ideal for practice, what is the gain?

The gain appears to be philosophy's coinciding with itself. The transformation Rorty engages is not a positive transformation toward some standard or object. Rather, transformation in philosophy follows the failure of human interest to find certain intuitions powerful any longerwhen consensus fails and the mask drops away and we confront ourselves without these intuitions. The pragmatic transformation is essential for philosophy to meet its true character as holding fragmented pieces of our power together into a concerted effort toward whatever we can accomplish, while actively resisting any suggestion that our accomplishments mean any thing like the realization of an ideal character or obedience to some remote end. The loss of interest in these ideals and ends 
makes this true character apparent, and the pragmatist must herewith live in good faith, and in good style. David Hume could not do better.

From this platform of pragmatism, Rorty can evade all reflection that could possibly generate a converting demand on reason. This aggressive evasion comes out clearly in his response to William James's "The Will to Believe." Rorty agrees with James that "[b]oth scientific realism and religious fundamentalism are private projects which have got out of hand. They are attempts to make one's own private way of giving meaning to one's own life - a way which romanticizes one's relation to something starkly and magnificently nonhuman, something ultimately True and Real-obligatory for the general public."16 Rorty cannot endure the sense of universal obligation apart from one's power any more than James can. Religious faith is not anything like respect:

The kind of religious faith which seems to me to lie behind the attractions of both utilitarianism and pragmatism is, instead, a faith in the future possibilities of moral humans, a faith which is hard to distinguish from love for, and hope for, the human community. I shall call this fuzzy overlap of faith, hope and love "romance." Romance, in this sense, may crystallize around a trade union as easily as around a congregation, around a novel as easily as around a sacrament, around a God as easily as around a child. ${ }^{17}$

While this vision avoids the problem of universality, this "romantic" vision is not completely compatible with James. Rorty acknowledges James's moods where he needed the assurance that "somewhere, somehow, perfection is eternal." James's interest in religious experience led him to seek an understanding of that ground that would enable him to cut through hard and fast distinctions and get closer to the ideal of perfection. But sometimes working through distinctions is not enough, and James recognizes his need for a confirmation of the effectiveness of this activity. "All of us, I think," Rorty admits, "fluctuate between such moods. We fluctuate between God as a perhaps obsolete name for a possible human future, and God as an external guarantor of some such future... Those who, like me, were raised atheist and now find it merely confusing to talk about God, nevertheless fluctuate between moods in which we are content with utility and moods in which we hanker after validity as well. . . . Sometimes it suffices to trust the human community. . . . Sometimes it does not."18

Rorty takes exception to the argument in "The Will to Believe" where James calls upon faith in order to fill up this ground for trust 
when the community fails. At these moments, James focuses on the cognitive effect of faith. Faith gives us some facts to live on. Rorty reacts: "This attempt to answer questions of justification by discovering new objective truths, to answer the moral agent's request for justification with descriptions of a privileged domain, is the philosopher's special form of bad faith - his special way of substituting pseudo-cognition for moral choice." ${ }^{19}$ But he misses James's point, made more clearly in Varieties of Religious Experience, that if there is a difference to be made to life at all through religious faith, it must have cognitive dimensions:

Religion ... is not a mere illumination of facts already elsewhere given, not a mere passion, like love, which views things in a rosier light. It is indeed that, as we have seen abundantly. But it is something more, namely a postulator of new facts as well. The world interpreted religiously ... must have ... a natural constitution different at some point from that which a materialistic world would have. ${ }^{20}$

James is not searching for philosophical justification the same way Rorty is. James is engaging what happens in religious experience, presumably his own. Unlike James, Rorty's philosophical categories overdetermine what he can experience. (Once an epistemologist, always an epistemologist?) Rorty struggles to account for the power of James's analysis when the desire for justification takes a backseat to the cognition of the self that is engaged when a person says, "I should never do that again, and by God, I won't." How would such an event not be cognition? Rorty seems to have forgotten Hume's charge, "Be a philosopher, but, amid all your philosophy, be still a man." 21

I think Dewey's emphasis on the problems of men and women is the heart Rorty knows he needs. Rorty sees the celebration of power in pragmatism, but Dewey sees an obligation to orient that power to the service of growth in others and in the community. Dewey adjusts philosophical power to these ends, not to "extirpate" questionable ones but to fructify common ones. Philosophy asks not what belief it is possible to hold, but what is necessary to explain the movement toward a deeper involvement with the well-being of my community and myself. What makes sense of the obligation that holds me? What ground does my hope seek, and in what ways does this hope translate into a community of shared purpose and desire? If Dewey is out of step with the desire of his community, he knows he has failed. For Rorty, being out of step with the community just means that it has failed. He is more like James in this 
way, where the risk is that he might wind up with a novelist's faith, without a community except as material for criticism. But even this faith can enable hope to crystallize around some feature of experience that develops into objects of action if they have sufficient and compelling power over us. Rorty wants neither Dewey's common faith nor James's mysteriously objective faith, and so Rorty cannot explain his own ground. His replacement of the power of the Christian vision of transformation with pragmatism works until his image of the pragmatist, founded on James and Dewey, dies for lack of sustenance. His desire to evade conversion leads to an incoherence in his philosophical backing and undermines his attempts to find a platform for creative philosophy. To put this criticism in his own words, Rorty's pragmatism does not pay off.

Rorty's service to philosophy is another epistemic iteration of philosophy itself. Epistemic transformation like this fails, however, because there is no awareness of conversion, the kind of demand that enlivens human reason by facing it with what it cannot supply. Rorty tries to supply romance, a personally meaningful attachment to an item, as a replacement for conversion. But romance is possible only from the position of detachment from the prospect of the community. Romantic vision cannot be demanded and any obligation to the community is strictly nominal and voluntary. If the community fails, the romantic is unscathed. Rorty achieves, by religious faith oddly enough, a complete detachment from the expectations of good desired by the community, and the fear of failure.

Robert Neville, listening to Rorty's essay on James several years ago, responded, "The wisdom writer says "The fear of the Lord is the beginning of Wisdom.' Where is fear in your understanding?” Rorty answered that fear does not have a place in determining right thought or action. But where then, I ask, is risk? Is the Heideggarian riskiness Rorty seeks just the risk of not getting what we want? Is not risk based to some degree on fear, the fear that we might not be who we must be? This fear and respect grounds the reflection of James and Dewey. Working in the fear and respect of the culminating effect of action is, I think, central to the pragmatic spirit of caring for what is produced by our labor. This is the fruit by which we know ourselves. For Rorty transformation is a choice, like a wish for a designer personality, not the satisfaction of a demand we cannot help but serve. Rorty reduces the transformation of the pragmatists to an epistemic problem, and in the process he evades 
implicating himself in the transformation that might convert us and our community into a truly human community.

\section{Cornel West, Transformation of Culture, and Conversion}

Shifting the locus of philosophy from the traditional intellectual arena to the pulpit requires a radically different understanding of philosophical inquiry than is usually presupposed; and it is a difference Cornel West is at pains to describe, defend, and proclaim. But at the base of this description and defense is the simple but profound test he claims is the final arbiter of the success of a thinker, of a philosophy, of a preacher: "Is the word spoken potent, to common folk?" 22 The transformation West hopes to encourage in American culture and intellectual life would constitute a conversion not only to the gospel of Christ but also to this kind of potency.

Cornel West transforms American philosophy by raising questions of social analysis, communication, and authority. Philosophy is not measured by theoretical power or academic brilliance, but by the usefulness and applicability of the thinker's thoughts and words, about the modeling of an organic intellectual-by persuasion. West may not precisely model the prophetic preacher he describes, but he is insightful and helpful in getting to the philosophical conception of prophetic speech he desires. My interest here is to explore West's radical religious historicism as another permutation of evading conversion. Since his philosophy more than others stands on conversion, I offer a suggestion to enrich West's account of prophetic pragmatism at this point. My suggestion moves along the double axis of confession and prophecy, where doing and being coincide and where structure matches content.

\section{Prophetic Philosophy}

Cornel West's work on the American evasion of philosophy was the subject of a symposium issue of Praxis International. In this evaluative project, the tension between participatory and egalitarian models of democracy was at the forefront. The tension is this: do we need a democracy where the access to basic human needs is equally free for all-an egalitarian society-or do we need more than that-a society where involvement is encouraged and where political power is spread among all the people? Richard Rorty finds the first sufficient, but West argues that a fully participatory democracy is desirable. ${ }^{23}$ West bases this claim 
to full participation on his understanding of the Christian gospel as the affirmation of every individual's importance.

West's desire to articulate and encourage this sort of democracy stems from two fundamental orientations: the influence of his black Baptist religious heritage and his commitment to Marxist social analysis. His religious heritage reflects a basic connection with American philosophy and with the pragmatism of John Dewey. His descriptions of the black religious environment almost seem to equate the reality of religious dissenters, who gave the African Americans their church polity, with the reality of the pragmatist tradition that works and hopes for change in a fallen world. This religious heritage has built into it the question of the severity of the fallenness of the world. For the "light fall" conception, reconstruction of the tragic circumstances of the world is possible. For the conception of the "hard fall," only destruction and complete re-creation will work. Here is the tension between institutional reconstruction or destruction, between Dewey and Marx, which emanates from the religious predicament of American blacks. The necessary function of individuals and communities in social reconstruction is located along this line of tension, where the question is, which institutions require destruction and which require reconstruction? Individuals engage in the social analysis that identifies these barriers and instantiates the hope for change that sustains the movement toward a more healthful social democracy. West's prophetic call for philosophy blurs the distinction between individual and communal responsibility, relying on individual awareness to identify socially repressive institutions. The prophetic aspect of his philosophy merges with his notion of prophetic Christianity, which he describes this way:

Prophetic Christianity has a distinctive, though not exclusive, capacity to highlight critical, historical, and universal consciousness that yields a vigilant disposition toward prevailing forms of individual and institutional evil, an unceasing suspicion of ossified and petrified forms of dogmatism, and a strong propensity to resist various types of cynicism and nihilism. Prophetic Christian conceptions of what it is to be human, how we should act, and what we should hope for are neither rationally demonstrable, nor empirically verifiable in a necessary and universal manner. Rather, they are embedded and enacted in a form of life- a dynamic set of communities that constitute a diverse tradition-that mediates how I interpret my experiences, sufferings, joys, and undertakings. There are indeed good reasons to accept prophetic Christian claims, yet they are 
good not because they result from logical necessity or conform to transcendental criteria. Rather, these reasons are good because they are rationally acceptable and existentially enabling for many self-critical finite and fallible creatures who are condemned to choose traditions under circumstances not of their own choosing. To choose a tradition (a version of it) is more than to be convinced by a set of arguments; it is also to decide to live alongside the slippery edge of life's abyss with the support of the dynamic stories, symbols, interruptions, and insights bequeathed by communities that came before. ${ }^{24}$

West calls his own religious commitment "Kierkegaardian," emphasizing its fideistic nature that resists philosophical description or defense. This platform of faith is West's only attempt to place the individual who engages in the prophetic political struggle for human dignity and operates at a critical level rooting out deep-seated (social) idolatries. ${ }^{25}$

The substance of West's prophetic approach is a formula of critique that he applies with unfailing rigor to all political and philosophical positions, including his own. This formula examines three aspects of any position: its uncriticized presuppositions, its program for (or lack) of social analysis, and its existential identification with the downtrodden. These principal tenets are West's formulation of the residual elements of the strategies African Americans adopted in order to survive their slave status and develop a center for their communal life. Evaluation and appropriation of alien narratives can function only because survival strategies are fallibilistic and open for change. It is this reading of the gospel that is the unreasoned and indefensible platform of West's philosophy. He claims that this gospel presupposition can be critically accepted because it is rooted in the historical fact of the black experience and the historical fact of the crucifixion and resurrection of Jesus. There is no metaphysical "backup" to this position, only a historical commitment. What makes West's presupposition critical is its dependence on the black tradition as a historical context of survival, and West's selective appropriation of this tradition because of its particular existential appeal to him. ${ }^{26}$

The last general thing to say about West's prophetic philosophy before we examine his historicism is that he rejects metaphysics in the old style because such systems are idolatrous, raising closed systems up as the real objects of veneration, and also because they have no commerce with our daily lives. It doesn't make a real difference. West's Deweyan side overshadows his Peircean side and with a sweeping hand 
he displaces universal description with local description. Prophetic philosophy, then, can speak only a local dialect, and the extension of his program must evolve on ad hoc terms.

\section{Religious Historicism}

For West, context is the crucial feature of all dialogue. The context is the source for all standards of judgment, theories, and conceptions. But context is not primarily a key to critical thought-it is the source and final articulation of the meaning of our philosophical and political activity. West holds the existential appeal of a narrative, like that of the black religious tradition, together with a critical reflection of that narrative that involves evaluating other neighboring narratives. The glue that bonds existential appeal with the critical philosophical reflection of prophetic speech is the fact that historical appropriations have made the black narrative what it is, and present circumstances demand that new strategies be found so the narrative can continue.

This interplay of religious and philosophical discourse is held together by the context defined completely by the institutional apparatus that happens to be present and by the strategies that are being used to survive. So, for instance, the historical adoption of the Christian narrative that comprises the categories of realized triumph over evil in the resurrection of Jesus, as well as the intense longing for relief from present suffering in the category of eschatological hope, is reciprocated by critical reflection that comprises the present overcoming of the vestiges of sexual, gender, and ethnic power structures (Foucault), as well as the hope of social reformation through Marxist social analysis. West holds that Christian faith carries an implicit connection to radical individualism and Marxist analysis which appeals to the felt needs of our present social existence and provides a platform for speaking to other narrative traditions about the central issues of social democratic life. West's critical reflection, mediated through his historicism, is a combination of appraisal, metaphysical reflection (without universal implications), and prophetic speech that calls for a political struggle for human dignity. It is clear that West's analysis is on a different foot than traditional philosophical criticism.

Because of this difference in West's aim and method, his speech is hard to criticize in traditional ways. Let me turn from exposition to a more critical appropriation of prophetic pragmatism that is possible from a 
platform sensitive to the issues of conversion. Two points of criticism arise here. The first is that there is an imbalance in West's historicistprophetic project. The existential appeal that draws a person into this narrative is not matched in richness by the speech and historicistic metaphysical reflection West describes. West says that the critically reflective prophet philosopher speaks out of his existential condition, but there is something else involved in the need for existential salvation that does not correspond to prophetic speech. West's prophetic speech does not speak from the existential condition fully; and it is a truncated speech because there is no call for existential conversion implicit in it. Existential conversion is richer than the result of critical reflection and demands richer philosophical categories than West has supplied.

Let me put this point another way. The last chapter of The American Evasion of Philosophy is West's most complete description of his prophetic pragmatism.

Prophetic pragmatism affirms the Niebuhrian strenuous mood, never giving up on new possibilities for human agency — both individual and collective-in the present, yet situating them in light of Du Bois' social structural analyses that focus on working-class, black, and female insurgency. Following the pioneering work of Hans-Georg Gadamer and Edward Shils, prophetic pragmatism acknowledges the inescapable and inexpungible character of tradition, the burden and buoyancy of that which is transmitted from the past to present. ... [P]rophetic pragmatism denies Sisyphean pessimism and utopian perfectionism. Rather, it promotes the possibility of human progress and the human impossibility of paradise. This progress results from principled and protracted Promethean efforts, yet even such efforts are no guarantee. . . Human struggle sits at the center of prophetic pragmatism, a struggle guided by a democratic and libertarian vision, sustained by moral courage and existential integrity, and tempered by the recognition of human finitude and failure. ${ }^{27}$

West is clear that his turn to Christianity through the black church was the beginning of his turn to prophetic philosophy. Christianity was the existential side of the content he now articulates philosophically. In this same context West makes the claim that prophetic pragmatism need not be tied to the Christian tradition, and that any tradition will do that is rich enough to sponsor this sort of critique.

Revolutionary Christian perspective and praxis pave this middle pathway [between liberalism and right-wing Marxism]. They are rooted in the 
world view found in the bosom of Afro-American culture and in the major institution which provides refuge from the terror in Afro-American life-black churches; they are informed by the social analysis and moral impulse of the best of the socialist movement-progressive Marxism; and they build upon, yet go far beyond, the prevailing viewpoint of the vast majority of Afro-Americans-black liberalism. Revolutionary Christian perspective and praxis incorporate the prophetic dimension of Christianity and eschew the paralyzing liberal outlook. ${ }^{28}$

Although West tries to make this inclusive move away from his tradition, he makes it at the expense of letting the uniqueness of his call disappear. His claim that any tradition will do means that he cannot call others to his specific tradition, which is Christian, but can only call others to recognize the call they might hear from their own tradition. This move to inclusion fails philosophically on two counts. First, it presupposes that West has articulated the essence of a "calling" tradition for prophetic pragmatism, where this tacit move to universality violates his own historicist criterion. Second, his inability to extend the same call he responded to as a speech fully adequate to his philosophical position undermines his claim that the call to the cause of Christ was sufficient to incorporate him into prophetic pragmatism in his own case. There is something in West's own entry into the fold of prophetic pragmatists that is not expressible in the kind of prophetic speech exemplified by his philosophical position.

My second criticism is that surviving, which is the essential activity at the heart of the black narrative, and West's Marxist analysis, do not appear to be held together either by self-reflexive discourse or by metaphysical reflection. West does not persuasively explain why applying Marxist analysis to the world and evaluating competing narratives on these terms is essential to the tradition of surviving. ${ }^{29}$ West needs to define "surviving" in a richer way if he is going to claim that something as radical as Marxist analysis is necessary for achieving that goal.

Let me expand this second critique. West claims that individualistic and democratically egalitarian themes of the gospel are appropriated selectively from a tradition that itself is appropriated selectively from a larger tradition. But he argues as if this selective appropriation is grounded on an authoritative principle called "the gospel" that transcends the dialectic of appropriation and makes his reflective assessment of the nature of the gospel a critical rather than an uncritical belief. This 
gives his Marxist account a more stable warrant for acceptance than it deserves. Individualism and democracy as the foundation of the gospelat least to the degree that West uses these terms - seems a dubious claim.

For West, critical, selected strategies are fallibilistically held for specific purposes, and descriptions are limited to identifying strategies within a particular context. The general authority of the gospel in his tradition makes it useful for a general approach to the world, where new and different contexts are faced. West's move to combine the gospel and Marxism is embraced because it further expands the scope of a critical approach to problems, and because Marxism adds an intellectual core to the peculiarly contextual belief in Christianity. Christianity that speaks in Marxist idioms is somehow easier to defend than a strictly orthodox version of the gospel. A similar assimilation occurred with the historical introduction of theism as a philosophical-religious term around the middle of the seventeenth century as the "belief in the existence of a Supreme Being as the source of finite existence, with rejection of revelation and the supernatural doctrines of Christianity" to add intellectual clout to belief. ${ }^{30}$ Unfortunately, both this move toward theism and, I fear, West's toward Marxism undermine the very contextual peculiarity that vivifies the appeal of Christianity.

What is more troubling about this problem, though, is that West ignores or discards the dialectic between his Marxist tendencies and his understanding of the gospel he appropriates. He claims the two mutually support one another without considering the possibility that both may emerge from the prior ground of a social-political commitment. It is clear, however, why he would downplay this possibility of dialectic. It undermines his prophetic ground. What makes prophetic ground difficult to articulate is that the word spoken in the original context speaks just as well to remote contexts. West wants to replace this double-speaking word with a thoroughly spoken word that incorporates all contexts by virtue of its theoretical extension. This is West's attitude toward Marxist analysis. He thinks it can and must be applied to every social order. By contrast, I suggest that true prophetic ground is recognized by intensionally descriptive and extensionally applicable speech. A prophetic word, because it emanates from the intensional truths of divine/human intersection, extends to all human occasions. West's prophetic word speaks Marxist analysis as an extensionally descriptive analysis. This evasion of the intensional problems of identity and difference, of individual and 
community, soul and God, favors the expedient and high moral tone of a gospel based on extensional description. The failure of an extensionally descriptive analysis emerges when the need arises for prescriptive work - what should be done here and now? This determination cannot arise simply from description. ${ }^{31}$ What should be done in a particular place and time does not follow clearly from the Marxist description West provides. Something else is needed to give the prophetic word its kick into the rough and tumble of immediate action and change.

The distinction between intensionally descriptive and extensionally applicable speech versus extensionally descriptive speech is often difficult to articulate. Peirce gives us an example of this difference and its difficulty when he describes personality. Personality is "a connection between ideas [that] is itself a general idea" (CP 6:155). Vincent Colapietro unpacks the notion that personality is an idea by describing the semiotic system that Peirce constructs around ideas. The move from personality to ideas to the semiotic structure of thought and meaning provides a rich intensional description of the self. Yet Peirce struggles to describe the criterion that makes a personality distinct from other ideas, finally claiming that the discriminating nature of a person depends on the same character of reality as general terms. ${ }^{32}$ Intensional descriptions like Peirce's theory of personality cannot avoid metaphysics, which is one reason West has an aversion to them.

One of the virtues of Peirce's metaphysical account of personality is its structured vagueness. Peirce can tell us in systematic terms what a personality is, but this "telling" is not exclusionary because it carries such a wide range of possible articulations that inclusion in that descriptive nexus is possible. The abilities of others to see themselves "in" Peirce's intensional description is the test of that description's extensional applicability. If it fails to extend to every person Peirce's description has failed.

There is another reason West avoids the dual characteristic of intensional description and extensional applicability for his prophetic speech: it involves opening the content of his speech to indefinite examination with the possibility that any failure of that extended word results in its complete rejection as a failed description. But this is just the test that is applied to prophetic speech in the Bible: "I will raise up a prophet from among their countrymen like you, and I will put My words in his mouth, and he shall speak to them all that I command 
him. ... But the prophet who shall speak a word presumptuously in My name which I have not commanded him to speak ... shall die. And you may say in your heart, 'How shall we know the word which the Lord has not spoken?' When a prophet speaks in the name of the Lord, if the thing does not come about or come true, that is the thing which the Lord has not spoken" (Deut. 18:18-22). Prophetic speech in the Bible is more complicated than simple prediction, when one takes into account the self-referential and repeated prophetic themes that link periods of Israel's history together across radical shifts of demographics, politics, cultus, and location. The test of absolute accuracy outlined in Deuteronomy is the demand for completely general extensional applicability of the prophetic word intensionally described as the "word of the Lord." If West wants to speak prophetically he is bringing himself under a severe criterion.

\section{Confessional Historicism}

Introducing the need for intensional analysis throws up red flags in a postmodern world. Intensional analysis necessitates a return to metaphysics. It brings up the problem of special knowledge and the power politics of truth. But I want to bracket those questions for the moment and focus instead on what a return to intensional thinking might provide for West's account. And I still want to temper everything with his own fire-if there is no difference to lived experience, there is no truth. In opposition to West, I think this kind of difference is possible only through a return to metaphysics, to the intensional description of human nature, and to the place of confession in the philosophical style of Augustine.

West's philosophical beginning is not a fully confessional place. There are two reasons for saying this. First, according to the tenets of historicism, there is no reality to describe that exceeds our historical context. But confession implies the common feature of a human relation to God, where "God" is tenderly offered as an attempt to indicate either the creative source for such a confession, or, more strongly, as the creative source and the presence evoking that confession. Second, confession includes an intelligible account of the content of one's belief. Though this account need not be rational and deductively certain, it must be rational as intelligible, articulate, and well reasoned. The ground of confession is not the non-arguable ground West claims for himself. While giving good reasons 
for faith does not mean that anyone agreeing with the soundness of the reasoning is thereby forced to admit the conclusion, it must evoke some aspect of belief that differs from, say, the philosophical beliefs or political ideas that one holds. There is the third meaning of confession as the performative act of willing or admitting belief. This is different from faith as an intellectualism. Faith is more than theoretical knowledge because it also involves the heart, as Edwards and Peirce have said in their own unique ways. The problem for West is that his description of religious historicism leaves no room for individual conversion and confession that would be the necessary ground for radical personal change. Such a transformation cannot be completely articulated by the standards of judgment of the context, but rather indicates a radical shift in the orientation of a person's intentions in relation to reality. Dewey shows more religious sensitivity than West in this respect when he claims that the project of a better world is dependent on men and women of personal faith and a "settled act of the will." Dewey may not have understood conversion very well but he sensed the significance of this intensionally charged space for his democratic program.

Like Dewey, West knows that the fragmentation of the community needs to be overcome in order for social melioration to occur. West sees this problem, but his insistence on historicism demands that the ground behind ultimate commitments remains non-arguable. Like West's more generalized account, confessional historicism also speaks to the problem of identity within a community. The imbalance noted before between West's prophetic speech and his commitment to the black Christian community is reflected in another dimension in the appropriation of strategies for survival that constitutes any community. To say it simply, the appropriation of Christian themes and hopes by slaves had to mean more than what West calls "appropriation of strategies." The strategies found within the Christian community make sense only to those individuals who can identify themselves at the most fundamental levels with the Christian story. Strategies are not the blossom floating on the surface ready to by plucked by any passersby; strategies are habits like the trunk of a tree that is inseparable from the roots hidden deep in the ground. Appropriation of a strategy that can withstand the vicissitudes of real political life can stand only so long as the supporting reality of that strategy's narrative remains intact. The choice of strategies is not reduced by this view to an acritical "Pascalian wager," but is rather a judgment of the 
orientation of those narratives. Not just any narrative with attached strategies will do, but only those narratives that refract the orientation of $m y$ confessional narrative. The orientation of the narrative guides the contextual appropriation. West, in his sermonic moments, reflects this aspect of confessional historicism: "Heroic courage to hope [is] grounded in the groundless mystery of the Cross - a prophetic witness to the absurd love of Jesus in a fallen world that views such love as folly and appears to reduce such love to impotence." 33 Christianity is appropriate to this understanding of returning to the difficult circumstances-even to the understanding that this "return" is a proper way of instantiating the word of God. Jesus returned from death to the same social reality that worked to his crucifixion. The disciples were admonished to return to the hostile city of Jerusalem after Jesus ascended. Even the Christian apocalypse points to this return to the concrete and the problematic; for it is Heaven descending to Earth, not Earth escaping its limitations, that inaugurates the physical Kingdom of Heaven in the Revelation of John. The ability of narratives to enable a return to a specific place, to orient myself toward my finite context, lies at the heart of existential survival and life. But it is the orientation that makes the narrative potent, and orientations can be seen only when the narrative is taken as a mode of identification and not just the supporting and dispensable stem of a strategy.

Confessional historicism is my attempt to suggest a strengthening of the non-arguable ground under West's prophecy. I take West's nonarguable position as a limited platform for the ground of mystery in the world, which is the true space of individual change that I call conversion. West shares the loss of the Americans who fail in just this way. The confessional place I propose corresponds to the thematic character in American philosophy following on Jonathan Edwards's religious affections, C. S. Peirce's heart religion, William James's will, and John Dewey's conviction about preserving values. These philosophers, taken as a tradition, speak to the confessional community as the place of mystery and the ground of prophecy and also reveal the moments of absence or evasion of that confession. I think West is correct that the American philosophical tradition is the promising location for a development of prophetic philosophy, and my comments here should be taken as an effort to appraise critically and extend his analysis. West's evasion of conversion is one of the most instructive platforms for the continuing discovery of transformation and its limits. 


\section{ROBERT CORRINGTON AND THE TRANSFORMATION OF CONSCIOUSNESS}

Robert Corrington approaches the transformation of American philosophy from the side of cosmogenesis, inquiring into the origin of the emergence of order within nature. Human spirit reflects the impulses of the universe, the openings and resistances, and follows these openings as an invitation to probe into the reality of the order of the universe. There is no foundation, no authoritative guide, and no promise of security in this discovery. Confidence in this path of discovery emerges from the fact that the Christian tradition and all religious traditions are living communities flowing out of this probing activity. Corrington, like Peirce, refuses to make Kant's transcendental deduction, focusing instead on following out philosophical traces of reality as they imprint on religious, philosophical, and psychological practice.

Corrington, although comfortable and familiar with religious notions of transformation, resists conversion language as dangerous because it represents a closing down of possibilities of the interaction with the underconscious of nature and the "selving" activity indicative of human thought. In conversion probes are limited, novelty eliminated by a conception of the soul that is determined prior to its emergence. Corrington latches on to Peirce's notion of a "real" as an invitation to probe without a priori determination. The discovery of the real is an exercise of ecstasis for Corrington, a standing apart from the continuum of nature. Such work of ecstasis reflects the best of religion. Not that we must strive to be good without God, like Rorty, for that simply covers over a self-loathing and absence that will reemerge and devastate an individual. Rather, Corrington holds that the reality ingredient in the universe corresponds to human ecstasis, opening toward it but not requiring or demanding human transformation.

From this openness met with activity, ultimate meaning and purpose may emerge. Corrington, in my terms, proposes a transformation of conversion from a response to a defining content to the indeterminate content of ecstasis. His philosophical program, then, revolves around converting religion and philosophy to this expectation of ecstasis-and I think both uses of "conversion" here carry much of the same meaning. In this program Corrington follows Peirce's lead, but realizes he must go beyond this beginning. The final word on ecstatic naturalism is that it is 
unstable in just the way Corrington resists the stability of Peirce. He must always be beyond himself philosophically, for any repetition becomes a liability to collapse into representation. The question we will resolve toward is whether an argument for ecstasis avoids the same hegemony as "the" correct formulation of human transformation. I break Corrington's work into three main headings: (1) ecstasis and consciousness, which begins with Peirce; (2) semiotic limits and interpretive community, which emerges in relation to Royce; and (3) the underconscious of nature and the Encompassing. These three headings correspond to firstness, secondness, and thirdness, except that Corrington's third, the underconscious of nature, recurs strongly to Peirce's firstness with the additional content of religious "foldings" that provide Corrington the material for differentiation and identity within the indeterminate ground of the Encompassing.

\section{Ecstasis and Consciousness}

In some ways Corrington reflects Edwards's path in the Religious Affections, discovering the rules for the ways we are transformed. The massive difference between them, though, is that Corrington proceeds apart from the security of a tradition like Edwards, and he includes the discoveries of the depth psychologies of Freud and Jung. The blending of psychology and semiosis has a proper beginning in Peirce, but Corrington has to reorient our understanding of Peirce away from the brilliantly odd logician and Scholastic realist. In Peirce Corrington finds a man dislocated emotionally and intellectually, a melancholy man.

Peirce was a master of the art of advanced forms of signification. He could enter into several distinctive semiotic systems and codes with great ease and always find pathways for connecting them. Yet in doing so he pulled further and further way from the ground of signification, perhaps originally presented to him by his mother. I am persuaded that Peirce remained haunted throughout his life by a sense of melancholy loss, a loss felt on the fringes of all of his daring analysis of the basic structures of the world. ${ }^{34}$

Peirce struggled to find himself in relation to his founding culture of Harvard elitism and the dimensions of his distracted personality. Peirce, for Corrington, is an example of a person who blazes a novel way into understanding human spirit. This novel and trailblazing character supports further probing development of Peirce's thought. Identifying the 
tensions internal to Peirce's cosmology and semiotic psychology sets up Corrington's own novel moves. "Peirce," Corrington says, "vacillated between the kind of conversion hysteria that paralyzes all symbolic and linguistic functions, and the abjection or melancholy denial that flies into a hypersymbolic activity as if to fill the universe with signs so that the maternal and its sensed loss is drowned." ${ }^{35}$ This struggle with conversion is central to Peirce, and indeed to Corrington as well.

For Peirce the multidimensional character of the self is metaphorically described as a lake. The self is a matter of depth, amorphous like water, a surface that appears above a vastness within which gradients of reality are found by settling down into places that resist peering looks. From this womblike image, Corrington pictures the self emerging by pressing up and out of this indefinite character. Again, he follows Peirce; "Ontologically, self-control is what it is because of the depth structures of cosmic habit within the universe as a whole.... The human process derives its energies and vector directionalities from the universe. . . But this process is a healing one in which the individual welcomes the larger community into its self-constitution." 36 This point seems exactly right. The puzzle for Peirce, Corrington, and me, however, is how the human process derives these universal energies toward reconstitution, and what object or content makes this reconstitution possible and necessary. From this passage we see how the self remains powerful in Corrington's thought; the self is key. For Rorty philosophy remains key, for West the community is key. For Corrington the key is the self and the process of selving, although later we will see why Corrington removes the Augustinian metaphor of healing from his conception of the self.

This aspect of the evolving and emerging self in Peirce's cosmology comes to the fore in an extended rejoinder to Paul Carus, who attacked Peirce as a necessitarian. Carus took Peirce's argument for "real and general" law as a declaration of determinative regularity. Peirce clarifies that his sense of law is not that to which "the phenomena of nature always conform, or to which they precisely conform" (CP 6:588). Peirce locates the openness for this imprecise conformity in a passage that becomes centrally important for Corrington. Peirce first denies that absolute chance is "something ultimate and inexplicable," stating that the chaos to which he recurs is so irregular that existence does not express this merely germinal state of being. "Even this nothingness, though it antecedes the infinitely distant absolute beginning of time, is traced back to a 
nothingness more rudimentary still, in which there is no variety, but only an indefinite specificability, which is nothing but a tendency to the diversification of the nothing, while leaving it as nothing as it was before" (CP 6:612). Corrington develops this further,

The true originative power of the universe is a deep nothingness that is more of a tendency than an actual pool of diversified possibilities. We could call this the domain of nature's potencies... The potencies of nothingness are ontologically prior to the possibilities that obtain in what we could call the "lesser" nothingness. Lesser nothingness is the domain of nothingness of cosmic possibility and variety. This is a kind of possible objects and events. . . Lesser nothingness is the cosmic soup of possibilities that can become actualized whenever emergents take on habits. Deeper down is the greater nothingness that provides the metaphysical goad for cosmogenesis. ${ }^{37}$

This statement is the ground of Corrington's ecstasis, the standing apart possible within the "cosmic soup" that is the primordial origin of meaning and reality. His probe into Peirce's insight of the internally distinguishing fluctuations of greater and lesser nothingness constitutes his trajectory outlined in the next sections of this chapter. Corrington states the object of his inquiry clearly:

What inner logic determines the movement from greater nothingness (the potencies) to lesser nothingness (the possibilities) to the nascent world of generals (the forms)? Is God the agency within or behind this process, or is God too a product of this process? Peirce downplays the concept of divine majesty which would entail that the purpose of the world and its creatures is to worship its creator. Instead, he makes a case for human autonomy, arguing that God is concerned with establishing independent creatures who do not seek to become part of an all-absorbing divine presence. ${ }^{38}$

Corrington's transformative reading of Peirce begins from this distinction of autonomous selves and the movement of the universe. Corrington is conscious of this transformative reading, and I think we philosophers all read with a similar transformative goal. This is how I have sought to read Edwards, Peirce, James, and Dewey. These readings are the places where disagreements are possible, and thus this is the location of my problem with Corrington's reading. He privileges both the demand for autonomy above any law, which I do not think coheres with Peirce, and the notion that the ground of this autonomy can only be the 
primordial soup of nothingness. I take the soup of nothingness to mean "that out of which" law emerges, and God, as the mystery of that generation, as having a complement in human autonomy converging on the divine character of agapism, that also emerges out of the relative "nothing" of firstness. In relation to law, the origin is this abyss of indeterminacy. But Peirce is clear that law, not indeterminacy, is the path toward an explanation of how things work. I am not sure what Peirce would think about making firstness the locus of origin for emergent meaning. $\mathrm{He}$ might react as Kant did when he denied that anything productive can be said about noumena. In opposition to Corrington, then, I think there is a sense of reverence of the sacred in Peirce. Otherwise we are hard pressed to understand Peirce's desire to subordinate himself to the "Master" and enter communion as anything but a lapse of judgment.

\section{Semiotic Limits and Interpretive Community}

In this section I follow Corrington's consideration of a community that emerges from the potentialities described above in the cosmic soup of firstness. Corrington claims that community is not an outgrowth of consciousness, but a mode of responding to a lawlike real emerging from greater to lesser nothing. Hence, community is a feature of the transformation from dependence on consciousness to the recognition of the role of nature. Corrington develops this notion of community in opposition to the philosophical understanding that community is more like a consciousness or more like a text than an emergent character of nature. "Once nature is reduced to a secondary status," Corrington says, "the supremacy of human textuality takes over. The metaphysical ineptness of this devaluation of nature is evident in the pantextualism that sees everything, whether a person or an event, as a text for which there are no stable or reliable interpretations." ${ }^{39}$ The fight between textuality and community leads through the prospect of an interpretive community that is not based on a "text" in the way that privileges consciousness. Only if a community emerges within the interpretive act can text-consciousness be overcome in a positive way.

Corrington develops Peirce's rejection of foundationalism and Cartesian introspection connected with first principles. The failure of this introspection leads Peirce to the character of thought as signs. From this platform Peirce arrives at the notion that intuition must be exceeded with communal acts of interpretation. "Signs form living communities," 
Peirce says, and all human thought collects around God as a "living sign" that makes humanity one community through the self-critical advance of scientific inquiry. This is not the living community Corrington claims since he does not accept Peirce's panpsychism - that all that is, is mind. Instead, Corrington proposes that the living sign can only have as its interpretant the human community, for this is all that can be properly claimed from the origin of nature that Peirce turns away from. For community to be possible, according to Corrington, it must emerge within the semiotic flow from nature, and here he follows Royce's development of Peirce's assertion that "all hermeneutic acts are communal." 40

Royce moves beyond Platonic knowledge about experience, and James's dependence on experience, to a third kind of cognition; interpretation. "It is to this third cognitive process that, following the terminology which Peirce proposed, we here apply the name 'interpretation." Interpretation, Royce says, is the main business of philosophy. Its goal is the production of the Beloved Community, which functions to unite diverse hermeneutic acts through the (Holy) Spirit of loyalty. The Beloved community is "the Universal Church, the body of Christ" which is the paradigmatic community of interpretation. Royce completes his thought; "to interpret is to strive to see the world as God sees it and as we would see it in the ideal kingdom." 41 Loyalty in the act of interpretation is Royce's idealized form of the Beloved community that invests the thought of Walter Rauschenbusch and Martin Luther King with practical power. ${ }^{42}$

Royce says in The Problem of Christianity, "The World is the Community. The world contains its own interpreter. Its processes are infinite in their temporal varieties. But their interpreter, the spirit of the universal community - never absorbing varieties or permitting them to blend-compares and through a real life, interprets them all." 43 This expression of a world containing its own interpreter is the ground for Corrington's naturalized community. The community of interpretation functions as the horizon and perspective through which all signs "pass on their way to interpretive transparency." 44 Corrington is still after transparency, which entails avoiding consciousness since there is no way for transparency to emerge within such a mediating abstraction. He says, "By shifting the burden of semiotic theory in this direction, Royce made a bold advance beyond Peirce." 45 Corrington thinks Royce also draws toward the same insights as Gadamer while avoiding his language of mysticism. For Royce the goal is not language but community. Setting 
aside the locus of language, Corrington suggests that he can follow Gadamer, who "links the hermeneutic process to the evolution of human understanding toward a practical evocation of the Good with the life of the community. Understanding is not limited to texts but drives toward interhuman communication. Rhetoric and dialectic receive their grounding in the hermeneutic process of discussion, which allows individuals to enter into horizons not their own." 46 This movement into "horizons not their own" is an essential distinction for Corrington. Science cannot accommodate this movement. Explicit description cannot work the conversion from one horizon to another. Moving between horizons is essential for interpretive cognition, and this movement requires dislocating oneself from any single form or ground of reference.

The finite interpreter is not somehow added to an already preconstituted community as one more member but derives his or her very meaning only through those intersubjective transactions that enrich the scope and contour of the community.... A mind thus becomes an interpreter whenever the traits of self-reflection, temporality, and intersubjectivity function together to secure the ongoing hermeneutic process. ${ }^{47}$

Interpretation is an end in itself since this is the only stable ground of the community. Therefore, loyalty to the interpretive community entails breaking beyond horizons. This keeps the process moving, but still the question remains about what drives the interpretive urge. Corrington's charge against neopragmatism emerges with the following statement: "[I]ndividual liberty does not constitute a sufficient condition for the hermeneutic community. Some form of conscious convergence must also prevail as the locus of future aspiration for the members of the social order." 48 A conscious convergence is an emergent character within interpretive communities, but it cannot be preconstituted or dogmatic, and neither can it be the result of unconstrained liberty.

Corrington acknowledges the power of Christian symbols as aspects of the conscious convergence in "movement toward the Encompassing." The Encompassing is the final dimension of the sign function and it brings the sign relation into the sphere of religion. The Encompassing depends on no ontological ground, yet it "exerts its uncanny lure for human existence." 49

The symbol of crucifixion specifically denies that any human or communal value can be attached to this reality. The cross curiously inverts itself whenever we try to fill it with further human content. In its self-negation, 
the cross breaks open to that which vastly outstrips human categorial projections ... whether or not the cross is the most radical symbol of the Encompassing, it fulfills its role whenever emptiness takes the place of semiotic density. This emptiness is not a nihilistic absence of meaning but a radiant evocation of a different kind of meaning not circumscribed by the signs of the community and its interpreters. ${ }^{50}$

Meaning that is not circumscribed by the community appears to fall outside of Roycean loyalty. But Corrington's point, I think, is that interpretive acts, like the one related to the cross, are examples of the ecstasis that escapes the language horizon of Gadamer without becoming disloyal. Such hermeneutic acts tend toward expanding the richness of the symbols rather than their destruction, and only with this movement away from "semiotic density" is the ongoing process of interpretation preserved in the long run. The crux of human transformation is discovering this origin of an interpretation that opens out within the community, unconstrained by the community, but oriented toward the community. Again, a Christian image is important for Corrington: "For Royce, Paul was among the first of Western thinkers to probe into the dynamic structures of community and show how these structures are animated and deepened by the presence of the Holy Spirit as the agency of Christ through time. Paul's vision of love, as the divine/human expression of loyalty became the ethical core for his understanding of the community as the body of Christ." 51

The ground of the community is loyalty, and Spirit (or spirit, in Corrington's view) is the principle of interpretation that is the sign of that loyalty. Loyalty "brings us to a new knowledge of the self and its community." 52 But what is the end of this knowledge? What is it for? Loyalty to an interpretation translates into habits of action that still seek teleological ground in ways that we will explore next. Corrington bridges from this understanding of the interpretive community to a method of avoiding both foundationalism and pietistic models of Jesus as the guide for life. The interpretive community Corrington describes manifests a universal movement toward "transparency" with what is in the world.

\section{Underconscious of Nature: The Encompassing}

The last stage of Corrington's reorientation of Peirce's philosophy appears in A Semiotic Theory of Theology and Philosophy. In this book Corrington resolves many of his theoretical probes toward firstness and 
nature, and the community that emerges through this transformation. Corrington blends together semiotic and psychological expectations,

Instead of trotting out the old grammar of pathology and normalcy, it is far more illuminating to talk of a dialectic involving closure and selving. The former term refers to the perhaps innate need to freeze meaning horizons where they stand so that the functioning self is not brought into thematic awareness. Forms of local control and the tribal assume priority. The concept of "selving," on the other hand, denotes a much more complex process of living in the spaces where awareness encounters the unconscious of the self and the underconscious of nature. Jung's concept of "individuation," while somewhat heroic and narrow, provides an analogue to the selving process. Selving lies at the heart of the human process and, while deeply ambiguous, is a force leading to species enhancement. ${ }^{53}$

The creative aspect of this process is the discovery of this momentum through reflection on the selving process. The platform of selving Corrington describes collects impulses into a process without (as Royce said) blending interpreters, while providing sufficient ground for the resistance of the individual to emerge, like Edwards's notion of entity. The selving process reaches back to the discovery of a primal (if not originary) momentum within nature. Naturalism becomes ecstatic when it probes into its own "somber tone" to find an even deeper momentum within nature that also yields its own categorial array. So Corrington's philosophical inquiry retains Peirce's logic but with a different tone. Corrington emphasizes the "world melancholy" (which he says is "far more stoic than a romantic Weltschmertz") that forms the necessary foreground for a participation in the ecstatic potencies that are emergent from the underconscious of nature, as mediated through the unconscious of the self. "One of the central tasks of semiotic cosmology is to describe or evoke the traces within the products of the self to gauge how they may, or may not, point to the ever-receding, yet ever-spawning, abyss of nature-naturing." 54

Corrington's discovery of the melancholy of Peirce now makes sense, because in that character he sees the outline of participation in the emergent character of the self. He is careful here to respect Peirce's hesitation to locate a principle of individuation that is positive in terms of the structure of the self or understanding; hence the underconscious of nature is the ground of the unconscious of the self. Both reflect the limit of secondness, which cannot produce or reveal categories. In one sense 
the real abyss in the semiotic structure is brute experience or secondness - there is no way out or forward. Corrington says, "The category of secondness, as the name implies, refers to brute dyadic interaction that is prior to signification or fulfilled meaning. . . Resistance (a form of secondness) in the human order is rarely fully self-conscious, and part of the endless comedy and tragedy of the human process can be seen in our struggles to find clarity out of the sea of projections that emerge from us and return to us." 55

But secondness is not easily left, and while Peirce moves from secondness to thirdness, and Corrington from secondness back to firstness, I think the resistance of secondness holds much more significance for both their semiotic structures than they admit. Indeed, Corrington depends on an argument from resistance to overcome Peirce. He says that what Peirce failed to grasp was the "sheer otherness of the unconscious, even if he had a partial sense of the underconscious of nature with his primal category of 'firstness.' His doctrine of panpsychism made the unconscious too conscious in the sense that mentality is a trait found throughout nature in a vast continuum admitting only of degrees of instantiation." 56 What Peirce fails to consider is the secondness of unconsciousness, and with this evaluation Corrington dismisses his philosophical father. While Peirce charts a trajectory toward a reality that is far different from its origin (nature-to-mind), Corrington answers both sides of this transformation with a single term, nature, that acts as both origin and telos in producing the contours of consciousness. Corrington proposes a path of reflective returning that is a rejection of getting beyond the limits of nature. Yet within this return all the complexity usually associated with a divine or ontologically separate content remains:

Ecstatic naturalism clearly sides with the second trajectory, that which speaks of the holy or numinous that represents a fully natural process of sacred semiotic folds impacting on the human unconscious. Further, ecstatic naturalism remains friendly to those feminist theologies that also want to become free from vertical patriarchal language and to probe into the ways in which nature's own pulsations contain religious seeds. The deconstruction of the male language of neo-orthodoxy, where god is envisioned as speaking von oben (from above) to sinful humankind, is absolutely essential to a renewed semiotic cosmology in its religious dimension. ${ }^{57}$ 
Corrington merges the religious dimension of reflection with the turning toward firstness through ecstatic naturalism- the religious seeds give this turn to the abyss of nature-naturing a modicum of warrant via the hope of a satisfying transformation. My interest here is the way this emulates a kind of conversion, albeit one away from other forms of conversion. Corrington says the ecstatic naturalist does not respond to a word from above, presumably like Edwards would hold, and not from experience that privileges consciousness, nor from tradition like we see in West that reflects patriarchal patterns. Rather, the turn must be accomplished from a set of infinities discovered in the process of interpretive selving, moving from the actual infinite of things, to a prospective (hermeneutic) infinite, to an open infinite, and finally to a sustaining infinite, like Tillich's “ground of Being":

[T] he sustaining infinite is neither religious nor anti-religious; it is not creator, nor is it an agent in history or otherwise. It obtains prior to the distinction between good and evil, and prior to any axiological distinctions such as those aesthetic distinctions so prized in process forms of naturalism.... Thus the sustaining infinite lives on the cusp of the ontological difference between the two primal dimensions of nature. It does not sustain what lies "below" it, but lives horizontally, as it were, in the world of innumerable signs and sign systems. . . It sustains, nothing more, and nothing less.... The sustaining infinite provides the clearing within which both identities and scopes can unfold or not unfold. But it is directly relevant to neither. ${ }^{58}$

This sustaining infinite is also the generative ground from which both selving and the interpretive community emerge. The intersection of the community and individual, participating in the mutual aspects of selving, extends from religious ground to the work of social reconstruction:

[F]or a fragile and nascent interpretive community the self will be a precarious foundling that must raise its head and social body above the inertia of the conditions of origin that make it possible. Interpretive communities, whether they emerge from the social elite or the marginalized, are those communities that challenge the inert self-signs that are perpetuated by natural communities. If this process of critique moves into a postmodern horizon, the self actually becomes derailed and loses its emancipatory energies in an ersatz horizon that only seems liberating. But if the interpretive self reaches back into its conditions of origin in a creative way, and brings forth emancipatory energies from and through these prehuman conditions, the prospects of democratic reconstruction are heightened. ${ }^{59}$ 
While there is care here, the impulse of the sustaining infinite is negative to Royce's Spirit that at least implies a constructive image of the self. Rather, for Corrington, "the spirit simply is its clearing away; it is not a consciousness in its own right that actively goes after persons and their projections," and " $[t]$ here is no centered consciousness in the spirit that could be addressed by human consciousness, even though the spirit can be met in an I-Thou relationship. Lacking consciousness, it must be seen as a gradient that goes where there is a gap or opening in the semiotic world that needs to be transformed." ${ }^{\circ}$ Corrington moves us toward the Encompassing by virtue of its tendency to interpretation; but there is nothing here but a clearing. Conversion from nothingness to nothingness appears to be the only way Corrington can answer a transformation "from above."

With this description Corrington arrives at a significant moment in his struggle to transform Peirce, especially his susceptibility to conversion language:

Peirce argued that without some form of novelty, habits could not be broken and new laws could not emerge. Hence, for him, novelty is a necessary feature in personal and cosmic evolution. From the standpoint of the self, novelty is necessary for the fulfillment of the selving process as the novel irruption of signs can compel a new self-organization that encompasses past signs and brings them into a new configuration. Yet there is also the tendency to stress the novel traits too much, thus ignoring or abjecting the necessary antecedent conditions for their emergence. This abjection process can be seen most starkly in certain forms of religious conversion which abject the preconverted self as being no longer relevant to the new self that has emerged. Psychologically this is a dangerous move as it utterly ignores the continuing power of unconscious complexes to intrude in the life of the so called "born-again" self. Again, all novelty is novelty in certain respects and not others. ${ }^{61}$

In this passage, we see again the opposition Corrington finds in conversion that has a structure independent of a unique self. Corrington's objection is revealing, because conversion is much closer to what he aims at than he perceives. What he is arguing for is not very far from the ineffable demand for a change to an ineffable character that resists all rational depiction except as that which the self cannot control. The movement toward an "opening" here is not for some articulable good other than matching the selving impulse with the spirit ingredient in the 
human unconscious. Corrington senses this absence and elides the effect of the transformed sense of religious community with social reconstruction: "The utopian hope that can move our religious community past the stage of compassion into a stage of political and social action is a product of the conjunction of the selving process and the spirit. . . It is almost as if a gap opens up that has its own vacuum energy, drawing the self toward those centers of distorted energy that must be transformed through democratic transformation." 62 Overcoming socially distorted energy depends on the selving that originates individuals without consciousness. In this way democratic transformation is a demand for continuing openness and interpretation, not for some good intrinsic to social reality itself.

The coordination of the roles of the nutrient religious community and selving impulses leads Corrington to conclude that "if we were to combine the best of the Greek with the best of the Hebrew worlds, we could say that 'sacred folds' of nature are in some sense responsive to our own semiotic and moral probes, and that there are energies that are extra-human that can aid us in the process of moral growth." These powers are not "extra-natural, nor are they in a 'position' to give us a moral blueprint. Yet without their powers, we are truly at the mercy of semiotic inertia and blind habit." 63

Corrington evades conversion, as his objection to "born-again" language makes clear, in order to describe a different kind of conversion. Like Peirce, Corrington knows the structure of the self is a clue to the transformative potency in the universe, although Corrington rejects the content Peirce finds in God and his choosing to turn away from the abyss of firstness. Corrington seeks to correct Peirce's failure of nerve by displaying how it is precisely this turn toward the abyss of firstness that provides access to truly transformative ground for both individuals and communities. Corrington is more like James in this respect of turning toward mystery without closure, but Corrington is more systematic than James in seeing this turn as a rejection of all connection to consciousness, no matter how much common sense must be overcome. Corrington has Peirce's community without its ground in God, and he has James's mystery without his ground in the self-adjusting self. He is, in a way, mediating an old conflict between friends. Corrington locates an agreement between Peirce and James that transformation must extend from nature and reconnect with it, albeit with a change of content or 
form. Such a return needs an inbreaking content to overcome the inertia of habits. But Corrington's model does not carry us beyond the transformation that is immanent in nature. I think this is why "born-again" language shows up in this account - he still yearns for this kind of rebirth and reformation. Indeed, to be taken up by the momentum within nature, as Corrington describes, where habits are broken without imposing another content, would be a rebirth to an expectation that there is no separate dimension to be overcome for selving or interpretation to obtain. This absolute immanence contains ecstasis, and therefore conversion is a moment of nature that cannot, need not, move beyond itself. Corrington arrives at a dyadic conception of transformation; our conversion is not nature's conversion; nature is the self-same. This is a kind of stoicism, as Corrington admitted earlier, that fully rejects the Neoplatonic lift from fragmentation to the one.

What I appreciate about Corrington is his sensitivity to the fact that conversion is a fundamental aspect of all metaphysics and cosmology,just as metaphysics and cosmology are fundamental to philosophy and theology. Where I have difficulty with his inquiry is the reliance on absence as the category of personal understanding and individuation. He produces an equivocation of spirit as stillness and spirit as the vacuum that draws attention toward the places of semiotic openness and need. Unlike Royce, Corrington cannot abide the Spirit of Christ, only the spirit of Heideggerian absence.

\section{CONVERSION AND ITS EVASION}

Richard Rorty, Cornel West, and Robert Corrington exemplify the continuing relevance of conversion for American philosophy. In these philosophers we have seen active resistance to conversion, using conversion as a platform from which analysis extends, or recasting the ground of conversion. In response to these "evasions," I have tried to show the difficulties that emerge within these philosophies taken on their own terms. My argument is that the absence of engaging conversion is not a failure of moral will or the rejection of a standard; it is a kind of philosophical failure to face a challenge of the philosopher's peculiar strength. The challenge of conversion is that standing apart from this critical test reason flounders on a beach of its own making. 
The evasion of conversion also reveals it as a place of deep resistance to philosophy. Most clearly in James, but even in West, the non-arguable ground of conversion appears to cancel philosophical power or description. Conversion cancels reason, or at least it appears to do so. My larger argument has attempted to show that antipathy toward conversion does not reflect our tradition, but rather just the opposite. Historically, an ultimate transformation like conversion has been a fruitful platform for reflection. This means that philosophical resistance to conversion emerges from another level. The impulse to conversion reflects a willful dissatisfaction with the present self, community, or conception of reality. Philosophy does not handle this resistance well. For all of philosophy's character as critical reflection that embraces difference and change, a change like conversion stands over against philosophy as something it cannot affect except at the extreme limits of its power. In conversion, philosophy sees its dependence on human affections and desire. Philosophy evades this resistance and attempts to replace it with other forms of conflict more easily handled, as Rorty does, or describe the resistance as yet another feature of the continuum, as Corrington does.

Conversion entails an inbreaking content or reality that unsettles practice and overcomes the inertia of habit. Such an inbreaking content shatters categories. Rorty and Corrington provide two examples of resisting this kind of difficulty. Rorty is not interested in any inbreaking content, and Corrington reinterprets the continuum so that it has the signs of an inbreaking content without the categorial difficulties. West makes the inbreaking content the principle of his prophetic speech, but this content is opaque to philosophy. Edwards recognizes the inbreaking content of conversion, but resolves that if there is anything reason should do for us by which its value can be clearly measured, it is getting hold of this inbreaking character and feeling the categorial threat to its limit. Edwards does not want to become this content, but he wants to understand the world in which it breaks in and ourselves as the object and purpose of that inbreaking. Elevated consciousness is not his goal. Rather, the lives of people, transformed into living stabilities by virtue of this inbreaking and shattering word, interpreters of the signs of the divine, are his focus. Such people are living moments of divine transformation that together make the only satisfying argument for real change in the universe, that is, by constituting in their embodied existences the change of the present world into a different one, by the changing of themselves. 
Conversion in American philosophy will always be problematic. American philosophy moves around conversion and only occasionally toward it. Philosophical work comes in from the fringes, approaching and receding from this place. The transformation of both knowledge and knower, transformed and transforming communities, and the philosophical origin of transformation, which can also be the subject of transformation, comprise the movement in relation to the vital core of conversion. The philosophical challenge I have undertaken here is holding these aspects of transformation together in order to see these trajectories as a piece of a disposition in relation to conversion. The foundation of personal transformation becomes that of the community, which can follow these trajectories with open eyes, not fearing the discovery that may come, but realizing the continuity of all such transformations with the impulse behind American philosophy to seek and find this place of conversion.

\section{NOTES}

1. Richard Rorty, Consequences of Pragmatism (University of Minnesota Press, 1982), xvii.

2. Robert B. Brandom, ed., Rorty and His Critics (Blackwell, 2000), x.

3. Ibid., 236ff.

4. Richard Rorty, Philosophy and the Mirror of Nature (Princeton University Press, 1979), 126.

5. Herman J. Saatkamp Jr., ed., Rorty and Pragmatism: The Philosopher Responds to His Critics (Vanderbilt University Press, 1995), 71.

6. Rorty, Consequences, xxviii.

7. Ibid., $x x x$.

8. Ibid., xxxvii.

9. Ibid., xliii.

10. Ibid., 33.

11. John Pettegrew and Casey Nelson Blake, eds., A Pragmatist's Progress? (Rowman and Littlefield, 2000), 96.

12. Rorty, Consequences, 54.

13. Ibid., 31.

14. Richard Rorty, Essays on Heidegger and Others: Philosophical Papers (Cambridge University Press, 1991), 2:31.

15. Ibid., 2:48.

16. Richard Rorty, Philosophy and Social Hope (Penguin, 1999), 157. 
17. Ibid., 161.

18. Ibid., 163.

19. Rorty, Philosophy and the Mirror of Nature, 383.

20. William James, Varieties of Religious Experience (Penguin, 1982), 407-408.

21. David Hume, "An Inquiry concerning Human Understanding," in Modern Philosophy: An Anthology of Primary Sources, ed. Roger Ariew and Eric Watkins (Hackett, 1998), 493.

22. Cornel West, Prophetic Fragments (Eerdmans, 1988), 272.

23. Robert Westbrook, "Democratic Evasions: Cornel West and the Politics of Pragmatism," Praxis International (April 1993): 7.

24. Cornel West, The Ethical Dimensions of Marxist Thought (Monthly Review Press, 1991), xxviii-xxix.

25. West, Prophetic Fragments, 88.

26. Cornel West, Prophesy Deliverance!: An Afro-American Revolutionary Christianity (Westminster Press, 1982), 106ff.

27. Cornel West, The American Evasion of Philosophy (University of Wisconsin Press, 1989), 228-229.

28. West, Prophesy Deliverance, 145.

29. West, Prophetic Fragments, 121.

30. Nicholas Lash, Easter in Ordinary (London: SCM Press, 1990), 103.

31. Westbrook, "Democratic Evasions," 7.

32. John Smith, America's Philosophical Vision (University of Chicago Press, 1992), 44.

33. Hosford Dixie and Cornel West, eds., The Courage to Hope: From Black Suffering to Human Redemption (Beacon Press, 1999), 228.

34. Robert Corrington, An Introduction to C. S. Peirce: Philosopher, Semiotician, and Ecstatic Naturalist (Rowman and Littlefield, 1993), 22.

35. Ibid., 24.

36. Ibid., 115.

37. Ibid., 179.

38. Ibid., 200-201.

39. Robert Corrington, The Community of Interpreters (Mercer University Press, 1987), xii.

40. Corrington, Community of Interpreters, 10.

41. Ibid., 24.

42. Anthony Cook, The Least of These: Race, Religion and Law in American Culture (Routledge, 1997).

43. Corrington, Community of Interpreters, 26.

44. Ibid., 35.

45. Ibid., 35.

46. Ibid., 42. 
47. Ibid., 53.

48. Ibid., 58 .

49. Ibid., 61-62.

50. Ibid., 63.

51. Ibid., 69.

52. Ibid., 77.

53. Robert Corrington, A Semiotic Theory of Theology and Philosophy (Cambridge University Press, 2000), 36.

54. Ibid., 39, 41.

55. Ibid., 46.

56. Ibid., 53.

57. Ibid., 61.

58. Ibid., 112, 113 .

59. Ibid., 135.

60. Ibid., 166.

61. Ibid., 201.

62. Ibid., 214, 215.

63. Ibid., 224. 